\title{
CAN AUDIT COMMITTEE REDUCE REAL EARNINGS MANAGEMENT?
}

\author{
YULIUS KURNIA SUSANTO \\ ARYA PRADIPTA \\ Trisakti School of Management, Jl. Kyai Tapa No. 20, Jakarta, Indonesia \\ yulius@tsm.ac.id, arya@stietrisakti.ac.id
}

\begin{abstract}
The objective of research was to give empirial evidence the influence of audit committee and directors on real earnings management (REM). The samples of this research consist of 336 data from 84 public manufacturing companies from 2013 until 2016 and selected by purposive sampling method. The result showed that the audit committee expertise and independence directors have significantly and postive influence on REM. The board of directors have significantly and negative influence on REM. The influence of audit committee tenure, size, meeting on REM is not significantly. The results of this reasearch shows that outsider of the firm like audit committee and independence directors can't detect REM. The chance for management doing REM. While, board of directors as insider of the firm can detect and reduce REM.
\end{abstract}

Keywords: Audit committee, directors, independence directors, real earnings management

Abstrak: Tujuan penelitian untuk memberikan bukti empiris pengaruh komite audit dan dewan direksi pada manajemen laba riil (MLR). Sampel terdiri 336 data dari 84 perusahaan manufaktur publik dari tahun 2013 hingga 2016 dan dipilih dengan metode purposive sampling. Hasil menunjukkan bahwa pengaruh keahlian komite audit dan direktur independensi terhadap MLR adalah signifikan dan positif. Pengaruh dewan direksi terhadap MLR adalah signifikan dan negatif. Pengaruh masa jabatan komite audit, ukuran komite audit, rapat komite audit terhadap MLR tidak signifikan. Orang luar perusahaan seperti komite audit dan direktur independensi tidak dapat mendeteksi manajemen laba riil. Peluang bagi manajemen melakukan manajemen pendapatan nyata. Sementara, dewan direksi sebagai orang dalam perusahaan dapat mendeteksi dan menurunkan MLR.

Kata kunci: Komite audit, dewan direksi, direksi independen, manajemen laba riil

\section{INTRODUCTION}

Earnings management (EM) is defined as the company cheating by increasing profits so that investors are interested on the company. However, many investors are deceived by very high profits. This happens because of the weak control in the company and causes the company not to be managed efficiently, in the long run it affects the performance and growth of the company (Susanto, Pradipta, \& Djashan 2017).
The public companies to have audit committee $(\mathrm{AC})$ and directors to cover the existence of EM in Indonesia. Corporate governance is relationship between company owner, shareholders, directors, commissioners in order to achieve company goals. It is important for companies to have $A C$ and directors in company so that they can suppress the existence of EM in company (Susanto, Pradipta, \& Cecilia 2019; Zarkasyi 2008). 
Since REM distorts financial reporting, the important task of directors and $A C$ is to provide certainty regarding the integrity of financial reporting. Audit committee can improve the credibility and quality of company's financial statements (Sun et al. 2014). Although AC plays a key role in overseeing financial statements, but with an unclear reporting process, audit committee can effectively inhibit REM. The research question is whether expertise, tenure, committee size, meeting, directors, independence directors affect REM.

\section{Expertise and REM}

AC who has financial and accounting expertise can facilitate company in seeing more effective financial reporting processes. Be'dard et al. (2004) and Lin et al. (2006) state that financial expertise have negative effect on EM. While, Susanto (2013), Sun et al. (2014), Pamudji and Triharti (2010), Susanto and Pradipta (2016) found different results which stated that expertise had no effect on EM. This shows that the establishment of $A C$ with competencies in accounting and finance is mandatory in the regulations.

AC who has field of accounting and finance had a positive effect on EM (Krishnan \& Visvanathan 2008). The research found that AC consisting of at least one financial expertise would reduce EM. AC that are experts in accounting and finance can pressure management to do REM. The hypothesis is:

$\mathrm{H}_{1}$ Audit committee expertise affects on REM.

\section{Tenure and REM}

$A C$ on behalf of commissioners representing the owner has the duty and function to oversee the financial reporting process so that no manager's behavior will harm the owner. Longer term of $\mathrm{AC}$, better understand the characteristics of management in managing the company (Prasetyo 2014). AC with a long term of office may have experience and expertise in auditing on financial statements. The tenure does not influence REM. AC is not effective in finding EM (Sun et al. 2014).

The average tenure had a positive influence on accrual quality (Dhaliwal et al. 2010). The length of the tenure has a positive influence on REM. Meanwhile, Bedard et al. (2004) found a negative relationship between aggressive EM and term of AC. The hypothesis is:

$\mathrm{H}_{2}$ Audit committee tenure affects on REM.

\section{Size and REM}

The large number of $A C$ is more likely to have a variety of skills to manage the practice of financial statements to be more practical (Baxter \& Cotter 2009). However, the large number of $\mathrm{AC}$ can be possible to deal with problems that can reduce the effectiveness of corporate arrangements (Sun et al. 2014).

The size proved to have no effect on EM (Al-Matari et al. 2012, Alkdai \& Hanefah 2012). This happens because the company's goal is to form audit committee just to fulfill mandatory OJK regulations (Agustia 2013). This is consistent with Sun et al. (2014), Susanto and Pradipta (2016) who assume that the size does not affect REM. Meanwhile, the size has a positive influence on REM (Kusumaningtyas 2014). The hypothesis is:

$\mathrm{H}_{3}$ Audit committee size affects on REM.

\section{Meeting and REM}

The meetings between members of $A C$ is expected to reduce the level of EM. AC that always hold meetings will continue to monitor and supervise the reporting process because with more and more meetings, it will not provide an opportunity for management to manipulate financial reporting because the AC will continue to be auditing (Prasetyo 2014).

AC activities does not affect EM (Pamudji \& Triharti 2010, Nasution \& Setiawan 2007). While, the frequency of meetings negatively affecting EM (Qi \& Tian 2012). The high frequency of meetings can reduce EM (Gulzar \& Wang 2011). The more frequency of 
meetings, the easier it is for AC to detect EM (Susanto \& Pradipta 2016). The hypothesis is: $\mathrm{H}_{4}$ Audit committee meeting affects on REM.

\section{Directors and REM}

The directors size is criticized with a variety of criticisms, where there is a relationship with optimizing company performance. Supporters from the theory agency showed that optimizing the number of directors can easily carry out internal communication and decision making (Jensen 1993, Yermack 1996). The large number of directors, with a specific knowledge, can benefit intercompany transactions (Pearce \& Zahra 1992). The directors size had a positive effect on REM (Talbi et al. 2015).

Directors is an important governance mechanism, because directors can ensure that managers follow the board's interests (Susanto, Pirzada, \& Adrianne 2019). A large number of board is less effective than a small number of boards. This is because the large number of directors will increase agency problems (Beiner et al. 2004). The hypothesis is:

$\mathrm{H}_{5}$ Board of directors affects on REM.

\section{Independence and REM}

The structure of directors is a key in the effectiveness of company. The presence of an independent directors can reduce conflicts in the company and management responsibilities (Susanto et al. 2019; Shleifer \& Vishny 1997). Some research questions the effectiveness of directors who are dominated from outside the company. Indeed, directors from outside the company have little information about the company's internal. The unique characteristics of REM techniques are needed to know broadly in terms of the company's operations. Talbi et al. (2015) states that the independence of directors has a positive effect on REM. The hypothesis is: $\mathrm{H}_{6}$ Independence directors affects on REM.

\section{METHODS}

The study sample used manufacturing companies public from 2013 to 2016 . Based on the sampling criteria, the number of manufacturing companies sampled was 84 companies. The sampling procedure can be seen in table 1. The collecting data uses secondary data. Data can be taken on the website, which can be accessed at http://www.idx.co.id.

\section{Table 1 Sampling}

\begin{tabular}{llcc}
\hline No & \multicolumn{1}{c}{ Criteria } & Firm & Data \\
\hline 1. & Public Manufacturing companies during the period 2013- & 132 & 528 \\
& 2016 & & \\
2. & Financial statements as of December 31 & $(10)$ & $(40)$ \\
3. & Rupiah & $(27)$ & $(108)$ \\
4. & Firms that do not have information about audit committee & $(11)$ & $(44)$ \\
& meeting & 84 & 336 \\
\hline
\end{tabular}
namely:

REM can be done in 3 (three) ways,

1) Sales Manipulation, the calculation (Sun et al., 2014):

$\frac{\text { CFO }_{t}}{T A_{t-1}}=a_{0} \frac{1}{T A_{t-1}}+a_{1} \frac{\text { Sales }_{t}}{T A_{t-1}}+a_{2} \frac{\Delta \text { SALES }_{t}}{T A_{t-1}}+\in(1)$
Abnormal CFO was the residual value of the equation (1). The higher abnormal CFO, the lower REM.

2) Discretionary Expenditures, the calculation (Sun et al., 2014): 
$\frac{\text { DISX }_{t}}{T A_{t-1}}=a_{0} \frac{1}{T A_{t-1}}+a_{1} \frac{\text { Sales }_{t}}{T A_{t-1}}+\epsilon$

Abnormal discretionary expenses was the residual value of the equation (2). The higher abnormal discretionary expenses, the lower REM.

3) Over Production, the calculation (Sun et al., 2014):

$$
\begin{aligned}
\frac{\text { PROD }_{t}}{T A_{t-1}}= & a_{0} \frac{1}{T A_{t-1}}+a_{1} \frac{\text { Sales }_{t}}{T A_{t-1}}+a_{2} \frac{\Delta \text { SALES }_{t}}{T A_{t-1}}+ \\
& a_{3} \frac{\Delta S A L E S_{t-1}}{T A_{t-1}}+\in
\end{aligned}
$$

Abnormal production cost was the residual value of the equation (3). The higher abnormal production cost, the higher REM. The measurement of variables are summarized in the following table.

\begin{tabular}{|c|c|}
\hline Variable & Measurement \\
\hline REM & $\begin{array}{l}\text { Sum of standardized of abnormal CFO, abnormal discretionary expenses, } \\
\text { and abnormal production cost. }\end{array}$ \\
\hline Expert & $\begin{array}{l}\text { The proportion of members that have accounting and finance working } \\
\text { experience in AC. }\end{array}$ \\
\hline Tenure & The proportion of members who served two consecutive periods in AC. \\
\hline Size & The size of $A C$. \\
\hline Meeting & Frequency of $\mathrm{AC}$ meetings. \\
\hline Director & The number of directors. \\
\hline Independent & The proportion of directors who come from outside. \\
\hline
\end{tabular}

Table 2 Variable Measurement

The study using multiple regression analysis, which will be, described the regression equation as follows:

REMt $=b_{0}+b_{1} \operatorname{Exp}+b_{2}$ Ten $+b_{3}$ Size $+b_{4}$ Meet + $b_{5}$ Dir $+b_{6}$ Ind $+e$

\section{RESULTS}

The descriptive of variable and result can be seen in Table 3 and 4:

Table 3 Descriptive

\begin{tabular}{lcccc}
\hline \multicolumn{1}{c}{ Var. } & Min. & Max. & Mean & Std. Dev. \\
\hline REM & $-1,664547$ & 2,585458 & $2,273 \mathrm{E}-16$ & 0,462712 \\
Exp & 0 & 1 & 0,782738 & 0,243417 \\
Ten & 0 & 1 & 0,387500 & 0,409885 \\
Size & 1 & 5 & 3,083333 & 0,493742 \\
Meet & 1 & 49 & 7,032738 & 6,202224 \\
Dir & 2 & 16 & 5,044643 & 2,464270 \\
Ind & 0 & 0.60 & 0,119022 & 0,145534 \\
\hline
\end{tabular}




\section{Table 4 Hypothesis Testing}

\begin{tabular}{lcc}
\hline \multicolumn{1}{c}{ Var. } & Coefficient & VIF \\
\hline Cons. & 0,268253 & \\
Exp & $-0,216278^{* *}$ & 1,022969 \\
Ten & $-0,010587$ & 1,030308 \\
Size & $-0,082546$ & 1,128470 \\
Meet & $-0,000492$ & 1,090357 \\
Dir & $0,038160^{* * *}$ & 1,139403 \\
Ind & $-0,305035^{*}$ & 1,042094 \\
\hline Adjusted $\mathrm{R}^{2} 0,053715, \mathrm{~F}_{6,329} 4,169320^{* * *}$ \\
${ }^{*}$ 10\%, ${ }^{* *} 5 \%,{ }^{* * *}$ 1\%,
\end{tabular}

Accounting and finance expertise (Exp) has positive effect on REM. The accounting and finance experts cannot detect is REM. AC is an external party their company does not have all the information about the company's real activities. This encourages management to do REM.

The tenure (Ten) does not affect REM. $A C$ is not effective in finding REM, but requires real activities in companies such as independent directors who have company data (Sun et al. 2014).

The size does not affect REM. This happens because the company's goal is to form an audit committee just to fulfill mandatory OJK regulations (Agustia 2013).

The meeting (Meet) does not affect REM. The meetings cannot detect REM. The meetings are conducted to fulfill corporate governance and are not effective in supervising management in conducting REM.

The director (Dir) has a negative influence on REM. The board of directors can suppress REM. They have all the information related to the company's real activities

The independence director (Ind) has a positive effect on REM. The independence of directors cannot suppress REM. The independent of directors has little information on the company's real activities. They cannot supervise management optimally. This makes management can do REM.

\section{CONCLUSION}

The conclusion of the research showed that expertise, board of directors, and independence directors influence REM. The tenure, size and meeting do not influence REM. The difficulty of outside parties in detecting REM can make management more free to do REM. The accounting information contained in the published financial statements cannot be used to detect REM. The need for more disclosure of the company's real activities in published financial statements and knowledge of audit committee and independent directors in detecting REM.

The future research uses trading company as samples. The future research uses AC gender that can affect REM. The further research using manufacturing companies from Southeast Asian countries that have similar characteristics but different cultural backgrounds, especially related to the behavior of $A C$ and independent directors in detecting the occurrence of REM. 


\section{REFERENCES:}

Agustia, D. 2013. Pengaruh Faktor Good Corporate Governance, Free Cash Flow, dan Leverage terhadap Manajemen Laba. Jurnal Akuntansi dan Keuangan, 15(1), Mei, 27-42.

Alkdai, H.K.H., \& Hanefah, M.M. 2012. Audit Committee Characteristics and Earning Management in Malaysian Shariah-Compliant Company. Business and Management Review, 2(2), 52-61.

Al-Matari, E.M., Al-Swidi, A.K., Fadzil, F.H.B., \& Al-Matari, Y.A. 2012. The Impact of Board Characteristics on Firm Performance: Evidence from Nonfinancial Listed Companies in Kuwaiti Stock Exchange. International Journal of Accounting and Financial Reporting 2(2), 310-332.

Baxter, P. \& Cotter, J. 2009. Audit Committees and Earnings Quality, Accounting and Finance, 49, 267-290.

Be'dard, J., Chtourou, S.M., \& Courteau, L. 2004. The Effect of Audit Committee Expertise, Independence, and Activity on Aggressive Earnings Management. AUDITING: Journal of Practice and Theory, 23, 13-35.

Beiner, S., Drobertz, W., Schmid, F., \& Zimmermann, H. 2004. Is Board Size an Independent Corporate Governance Mechanism?. KYKLOS, 57(3), Fasc., 327-356.

Dhaliwal, D., Naiker, V. \& Navissi, F. 2010. The Association Between Accruals Quality and The Characteristics of Accounting Experts and Mix of Expertise on Audit Committees. Contemporary Accounting Research, 27(3), 787-827.

Gulzar, M.A., \& Wang, Z. 2011. Corporate Governance Characteristic and Earnings Management: Empirical Evidence from Chinese Listed Firms. International Journal of Accounting and Financial Reporting, 1(1), 133151.

Jensen, M.C. 1993. The Modern Industrial Revolution, Exit, and The Failure of Internal Control System. Journal of Finance, 48, 831-880.

Krishnan, G. \& Visvanathan, G. 2008. Does the SOX Definition of an Accounting Expert Matter? The Association Between Audit Committee Directors Accounting Expertise and Accounting Conservatism. Contemporary Accounting Research, 25(3), 827-857.

Kusumaningtyas, M. 2014. Pengaruh Ukuran Komite Audit dan Kepemilikan Institusional terhadap Manajemen Laba. Prestasi, 13(1), 82-96.

Lin, J.W, June, F.L., \& Yang, J.S. 2006. The Effect of Audit Committee Performance on Earnings Quality. Managerial Auditing Journal, 21(9), 921-933.

Nasution, M., \& Setiawan, D. 2007. Pengaruh Corporate Governance Terhadap Manajemen Laba Di Industri Perbankan Indonesia. Paper Presented at Simposium Nasional Akuntansi X, Makassar.

Pamudji, S., \& Triharti, A. 2010. Pengaruh Independensi dan Efektivitas Komite Audit terhadap Manajemen Laba. Jurnal Dinamika Akuntansi, 2(1), 21-29.

Pearce, J.A. \& Zahra, S.A. 1992. Board Composition from a Strategic Contingency Perspective. Journal of Management Studies, 29(4), 411-439.

Prasetyo, A.B. 2014. Pengaruh Karakteristik Komite Audit dan Perusahaan terhadap Kecurangan Pelaporan Keuangan. Jurnal Akuntansi \& Auditing, 11(1) Desember, 1-24.

Qi, B. \& Tian, G. 2012. The Impact of Audit Committees' Personal Characteristic on Earnings Management. Journal of Applied Business Research, 28(6), November/December, 1331-1343.

Shleifer, A. \& Vishny, R.W. 1997. A Survey of Corporate Governance. The Journal of Finance, 52(2), 737-783.

Sun, J., Lan, G. \& Liu, G. 2014. Independent Audit Committee Characteristics and Real Earnings Management. Managerial Auditing Journal, 29(2), 153-172.

Susanto, Y.K. 2013. The Effect of Corporate Governance Mechanism on Earning Management Practice (Case Study on Indonesia Manufacturing Industry). Jurnal Bisnis dan Akuntansi, 15(2), 157-167.

Susanto, Y.K., \& Pradipta, A. 2016. Corporate Governance and Real Earning Management. International Journal of Business, Economics and Law, 9(1), 17-23.

Susanto, Y.K. 2017. Accrual Earnings Management, Real Earnings Management, Firm Value International Journal of Business, Economics and Law, 14(1), 1-6. 
Susanto, Y. K., Pradipta, A., \& Djashan, I. A. 2017. Free Cash Flow and Earnings Management: Board of Commissioner, Board Independence and Audit Quality. Corporate Ownership and Control, 14 (4-1): 284288.

Susanto, Y.K., Pradipta, A., \& Cecilia, E. 2019. Earnings Management: Esop and Corporate Governance. Academy of Accounting and Financial Studies Journal, 23(Special Issue 1), 1-13.

Susanto Y.K., Pirzada K., \& Adrianne S., 2019, Is tax aggressiveness an indicator of earnings management?, Polish Journal of Management Studies, 20(2), 516-527.

Talbi, D., Omri, M.A., Guesmi, K., \& Ftiti, Z. 2015. The Role of Board Characteristics in Mitigating Management Opportunism: The Case of Real Earnings Management. The Journal of Applied Business Research, 31(2), 661-674.

Yermack, D. 1996. Higher Market Valuation of Companies with a Small Board of Directors. Journal of Financial Economics, 40, 185-212.

Zarkasyi, M.W. 2008. Good Corporate Governance. Bandung: Alfabeta. 
